University of Nebraska - Lincoln

DigitalCommons@University of Nebraska - Lincoln

Faculty Publications, UNL Libraries

Libraries at University of Nebraska-Lincoln

2012

Human Trafficking in the United States. Part I. State of the

Knowledge

Anchalee (Joy) Panigabutra-Roberts

University of Nebraska - Lincoln, apanigab@utk.edu

Follow this and additional works at: https://digitalcommons.unl.edu/libraryscience

Panigabutra-Roberts, Anchalee (Joy), "Human Trafficking in the United States. Part I. State of the Knowledge" (2012). Faculty Publications, UNL Libraries. 290.

https://digitalcommons.unl.edu/libraryscience/290

This Article is brought to you for free and open access by the Libraries at University of Nebraska-Lincoln at DigitalCommons@University of Nebraska - Lincoln. It has been accepted for inclusion in Faculty Publications, UNL Libraries by an authorized administrator of DigitalCommons@University of Nebraska - Lincoln. 


\title{
Human Trafficking in the United States. Part I. State of the Knowledge
}

\author{
Anchalee Panigabutra-Roberts \\ University of Nebraska-Lincoln Libraries, Lincoln, Nebraska
}

\begin{abstract}
This article, the first of a two-part series, introduces the topic human trafficking in the United States. Based on the literature review, the author delineates definitions of "human trafficking," the extent and types of human trafficking in the United States, characteristics of trafficked victims and perpetrators, the human trafficking data reporting system, and examples of cases in the United States and its territories. The goal is to provide an introduction to this topic for library staff to use in their research and instruction services. Part II, to follow, is a survey of United States government web resources on human trafficking in the United States for publications and data.
\end{abstract}

Keywords: human trafficking, United States, review of research literature, trafficked victims, data collection

\section{Introduction}

Over the 12 years since the United Nations Protocol to Prevent, Suppress and Punish Trafficking in Persons (United Nations 2000) and the United States anti-trafficking law, Trafficking Victims Protection Act of 2000 (United States 2000), were passed and adopted, there has been more attention paid to human trafficking in the United States. This has resulted in an increase in research funding for this problem by the United States government (USG) agencies and nongovernmental organizations. USG agencies have also started to collect data on human trafficking in the United States and to provide information on human trafficking on their websites.

The author wishes to thank the editor and the anonymous readers for Behavioral E Social Sciences Librarian, and colleagues Kathleen Johnson and David Tyler, both at the University of Nebraska-Lincoln Libraries, for their editorial feedback and comments, which strengthened this article tremendously. Correspondence: Anchalee Panigabutra-Roberts, Metadata \& Multicultural Services Librarian \& Women's and Gender Studies Faculty \& Liaison, University of Nebraska- Lincoln Libraries, 322E Love Library, PO Box 884100, Lincoln, NE 68588-4100; email aroberts4@unl.edu 
This article, part I, serves as an introduction to and overview of human trafficking in the United States and is followed by a guide to USG web information resources on human trafficking in the United States. Part I addresses the state of knowledge on human trafficking (HT) in the United States, which covers the extent and types of human trafficking in the United States, characteristics of trafficked victims and perpetrators, the HT data reporting system, and examples of cases in the United States and its territories; part II, which follows, provides a survey of USG web resources for publications and data on human trafficking in the United States. The author has elected to include only published data but will identify the unpublished data whenever possible. The goal is to provide an introduction, overview, and a guide on HT for library staff to use in their research and instruction services. The article will also benefit new researchers, students, government agencies, nongovernmental organizations (NGOs), social service providers, and other users exploring this topic.

\section{Definitions of Human Trafficking}

Before further discussing the topic and reviewing the relevant literature, it is imperative to define the term "human trafficking" based on U.S. antitrafficking law. The United States adopted its first anti-trafficking law by ratifying a United Nations (UN) convention, United Nations Protocol to Prevent, Suppress and Punish Trafficking in Persons (2000), known as "the Palermo Protocol." Per the protocol, the term "trafficking in persons" was coined and defined as:

the recruitment, transportation, transfer, harbouring or receipt of persons, by means of the threat or use of force or other forms of coercion, of abduction, of fraud, of deception, of the abuse of power or of a position of vulnerability or of the giving or receiving of payments or benefits to achieve the consent of a person having control over another person, for the purpose of exploitation. Exploitation shall include, at a minimum, the exploitation of the prostitution of others or other forms of sexual exploitation, forced labour or services, slavery or practices similar to slavery, servitude or the removal of organs. (United Nations 2000)

The UN Protocol covers three types of human trafficking: sex, labor, and organ trafficking. Henceforth, the following abbreviations are used here: HT for human trafficking, LT for labor trafficking, and ST for sex trafficking.

The United States ratified the UN Protocol in the same year, to enact the Trafficking Victims Protection Act of 2000, known as TVPA (United States 2000). This act defines "severe forms of trafficking in persons" as: 
(a) sex trafficking in which a commercial sex act is induced by force, fraud, or coercion, or in which the person is induced to perform such an act has not attained 18 years of age; or,

(b) the recruitment, harboring, transportation, provision, or obtaining of a person for labor or services, through the use of force, fraud, or coercion for the purpose of subjection to involuntary servitude, peonage, debt bondage or slavery (United States 2000,8).

The U.S. law covers sex and labor trafficking, but not organ trafficking. This law provides assistance to trafficked victims in exchange for their providing assistance to U.S. law enforcement in prosecuting their traffickers. Subsequently, in 2008, the William Wilberforce Trafficking Victims Protection Reauthorization Act expanded the scope of HT law to include domestic workers and U. S. citizens and residents as trafficked victims, not previously covered by TVPA, as well (United States 2008). Since TVPA, many states have passed similar laws. According to the Polaris Project, as of August 7, 2012, 47 states and the District of Columbia have sex trafficking criminal statutes, and 49 states and the District of Columbia have labor trafficking criminal statutes (Polaris Project 2012).

\section{Literature Review}

The lack of reliable data on the nature and scope of human trafficking in the United States and other issues impacting research, information, and data resources on HT has been addressed and is still an ongoing concern for scholars and USG agencies alike. Goździak and Collett (2005) reviewed the literature on human trafficking in North America to find out about the funders and researchers on trafficking in human beings in North America, the methodologies and data sources used, the foci of the trafficking research, the types of studies conducted, and the research gaps that needed to be filled. They found that there was a lack of reliable data and transparent methodology for its validation, due at least in part to the development of research methods in this area being in its infancy (Goździak and Collett 2005, 121-22). A year later, the U.S. Government Accountability Office conducted a study to review U.S. international antitrafficking efforts and found that the USG's estimates on the number of trafficked victims across international borders $(600,000-800,000)$ was questionable due to methodological weakness, gaps in data, and numerical discrepancies, especially for the number of observed and estimated victims of trafficking (U.S. Government Accountability Office 2006, prelim. page). Musto (2009) pointed out problems due to the lack of a standard, scholarly, and precise definition of "trafficking"; this lack of standardization impacted the statistics on trafficked victims associated with the different definitions collected by 
researchers, agencies, and NGOs. Trafficked persons as a "hidden population" and the stigma associated with being trafficked and prostituted also made people less likely to talk to researchers (Musto 2009, 282). Musto also asserted that policymakers and law enforcement in the United States tended to consider all "irregular migrants," smuggled or trafficked, as criminals first until proven to be exploited (Musto 2009, 283). Since these studies, research on human trafficking has become more rigorous and research using a more systematic approach has been a priority for grants made by U.S. government agencies. Part I of this two-part survey focuses on what is known about human trafficking in the United States based on the new research using a more systematic approach and better methodology. As for library and information science literature, the author searched the database Library, Information Science \& Technology Abstracts (accessed on March 15, 2012) using the term "human trafficking" to find what has been written on this topic in this discipline (EBSCO Publishing 2005-2012). Of the 71 results, the majority are book reviews or analyses of news reports on human trafficking (in Index on Censorship), with one article on trafficking Internet brides from the perspective of information and communication technology law (Jones 2011). Only 26 of 71 results are published in scholarly (peer-reviewed) journals. Out of 71 results, only three publications assess and/or review the state of knowledge and resources on human trafficking in the United States. They are a bibliography on trafficking in persons in international and U.S. laws (Mattar 2004), an article on international resources on human trafficking (Stuart 2004), and a review of the website humantrafficking.org (Roberts and Drost 2010). Two of the three publications are dated. Two focused on international issues and legal aspects, and one reviewed only one website on human trafficking. Thus, this two-part survey will fill the gap in the library science literature on human trafficking by focusing on the problem in the United States and on the resources produced by the U.S. government agencies that have not been reviewed extensively in the library science literature. This survey may also serve as a complement to the recent review of resources on human rights by Kahl and Davis-Kahl (2010).

\section{Methodology}

For this part of the two-part survey, the author derived the content from her works and other resources as follows:

- A review of the literature included in the National Institute of Justice's research publications database, database searches in Thomson Reuter's Web of Knowledge, and catalog searches for books and government reports on human trafficking via the University of Nebraska-Lincoln Libraries and WorldCat catalogs. The author also searched the Inter- 
net/Google using the keyword "human trafficking" and visited the websites on human trafficking created by U.S. and state government agencies and antitrafficking NGOs.

- Human Trafficking Webliography (Panigabutra-Roberts 2009). The author created this catalog of websites between 2006 to 2009 by collecting the website URLs from various Internet resources, Google searches, books, reports, and articles on human trafficking and organized them by tags or keywords terms using Delicious, a social bookmarking service. As of March 20, 2012, there were 423 websites included in this catalog.

- University of Nebraska-Lincoln Interdisciplinary Conference on Human Trafficking Proceedings (2009-2011).

In summary, this article, Part I, will serve as an overview on the problem of human trafficking in the United States in general and is followed by Part II, a guide to the resources (i.e., publications and data) on human trafficking produced by U.S. federal government agencies.

\section{State of Knowledge on HT in the United States}

The Extent and Types of HT in the United States

Currently no agency has accurate data of the extent of HT in the United States. The difficulty in obtaining this data is due to the hidden nature of the crime, the uneven development of antitrafficking efforts at both state and local levels in the United States, and the lack of a centralized clearinghouse for HT information by the U.S. government. As for the scale of the problem of HT in the United States, studies reveal a rise in the number of HT victims found. Farrell et al. studied U.S. state and local law enforcement agencies and found that HT investigations increased from 175 reported cases in the year 2000, to 750 reported cases in the year 2006 (Farrell et al. 2008, 6). This study also found that the data on human trafficking can be uneven, due to the fact that $70 \%$ of the agencies investigating multiple HT cases investigated only one type of HT: $34 \%$ investigated only labor trafficking and $36 \%$ investigated only sex trafficking. The uneven use of time in investigation is another problem; most responding agencies reported spending more time investigating sex trafficking cases than labor trafficking cases according to this study. These are among the factors why data on human trafficking is, at best, a guestimate. Consequently, one needs to be skeptical and use scrutiny when reading or hearing of high estimates of HT cases in the United States and elsewhere.

Trafficked Victims

In the U.S. Attorney General's Annual Report to Congress and Assessment of U.S. Government Activities to Combat Trafficking in Persons (2011), each 
federal agency collected its own data related to its programs and services for trafficked victims. Notably, as an example of data related to foreignborn trafficked victims, for FY2010, the Office of Refugee Resettlement (ORR), which was responsible for the case management of foreign-born trafficked victims, issued 449 Certification Letters to adults and 92 Eligibility Letters to children, for a total of 541 letters issued. ${ }^{1}$ Additionally, ORR issued 12 Interim Assistance Letters to children, seven of whom later received Eligibility Letters (U.S. Attorney General 2011, 29).

Of the victims certified in FY 2010:

- $55 \%$ were male.

- $78 \%$ were victims of labor trafficking.

- $12 \%$ were victims of sex trafficking.

- $10 \%$ were victims of both labor and sex trafficking

- All victims of sex trafficking and all victims of both labor and sex trafficking were female. (U.S. Attorney General 2011, 29)

For child victims:

- $59 \%$ were female.

- $29 \%$ were victims of sex trafficking.

- $62 \%$ were victims of labor trafficking.

- $9 \%$ were victims of both labor and sex trafficking. (U.S. Attorney General 2011,30)

A large number of trafficked victims are in the labor trafficking category, since most labor trafficking involved large-scale cases such as those in the garment industry (the El Monte case) ${ }^{2}$ or farm industry (the Global Horizons case in Hawaii), ${ }^{3}$ for example.

The Human Trafficking Reporting System (HTRS) of the Department of Justice is a better source of data, as it includes both trafficked victims who are foreign-born and U.S. citizens and it is the only system that collects data from the investigations conducted by state and local law enforcement agencies. The data forming the basis for this publication, from Characteristics of Suspected Human Trafficking Incidents, 2008-2010: Highlights, indicated that more sex trafficking incidents than labor trafficking incidents were identified (Banks, Kyckelhahn, and U.S. Bureau of Justice Statistics 2011, 1). Federal agencies, however, were more likely to lead labor trafficking investigations (29\%) than sex trafficking investigations (7\%). (Note: Sex trafficking investigations were mostly led by state, local, or territorial level government agencies.) The other details on HT incidents in this report are:

- Federally funded HT task forces opened 2515 suspected incidents of HT for investigation, January 2008-June 2010, or in 21/2 years.

- $82 \%$ were sex trafficking (more than 1200 adults and more than 1000 children). 
- $14 \%$ were labor trafficking (350 incidents, with some overlap with sex trafficking; thus, more than $100 \%$ in total).

- $7 \%$ were an unknown trafficking type.

\section{HT Types: Varying From State-to-State}

Studies also showed that the emphasis on labor trafficking and sex trafficking seems to vary by state and region. California's task forces (California Department of Justice 2007) reported that between December 2005 and March $2007(n=58) 54 \%$ of human trafficking cases involved labor trafficking and $46 \%$ involved sex trafficking. Florida State University's Center for the Advancement of Human Rights (FSU-CAHR 2010) reported that since 2004, the majority of Florida cases prosecuted in the federal courts involved labor trafficking for both immigrants and U.S. citizens. On the contrary, Texas's Office of the Attorney General (2008) and Wisconsin's Office of Justice Assistance (2008) reported more sex trafficking than labor trafficking. However, the early labor trafficking study by Free the Slaves and the Human Rights Center at University of California-Berkeley (FTS and HRC-UC) (2005) found labor trafficking to be prominent in California, Florida, New York, and Texas. Farrell et al. (2008) added Arizona to this list of states where labor trafficking is prominent. In the past 10 years, Hawaii (Downes 2010) and other U.S. territories, such as American Samoa (FTS and HRC-UC 2005), also witnessed large-scale labor trafficking cases.

\section{HT Data Reporting}

Currently, at the national level, the 40 state task forces funded by the Bureau of Justice Assistance are the most well-equipped with the resources necessary for reporting data on human trafficking cases (Figure 1; U.S. Department of Justice Bureau of Justice Assistance and Office for Victims of Crime 2009).

While more published data are available, the true number of trafficked victims in the United States is still elusive, due to the hidden nature of the crime and to cases not being reported or investigated.

In response to the need to improve data collection, the U.S. Attorney General's report called for an increase in intelligence gathering on HT and for the creation of a national data collection mechanism to count and track HT cases brought under state laws (U.S. Attorney General 2010, 14-15). States can choose to include the mandate in the state law and to instruct agencies to collect data related to human trafficking.

\section{Types of Human Trafficking and the Characteristics of Trafficked} Victims and Perpetrators

The most common types of labor trafficking involve debt bondage, commercial agriculture, restaurant work, and the tourism and hospitality 


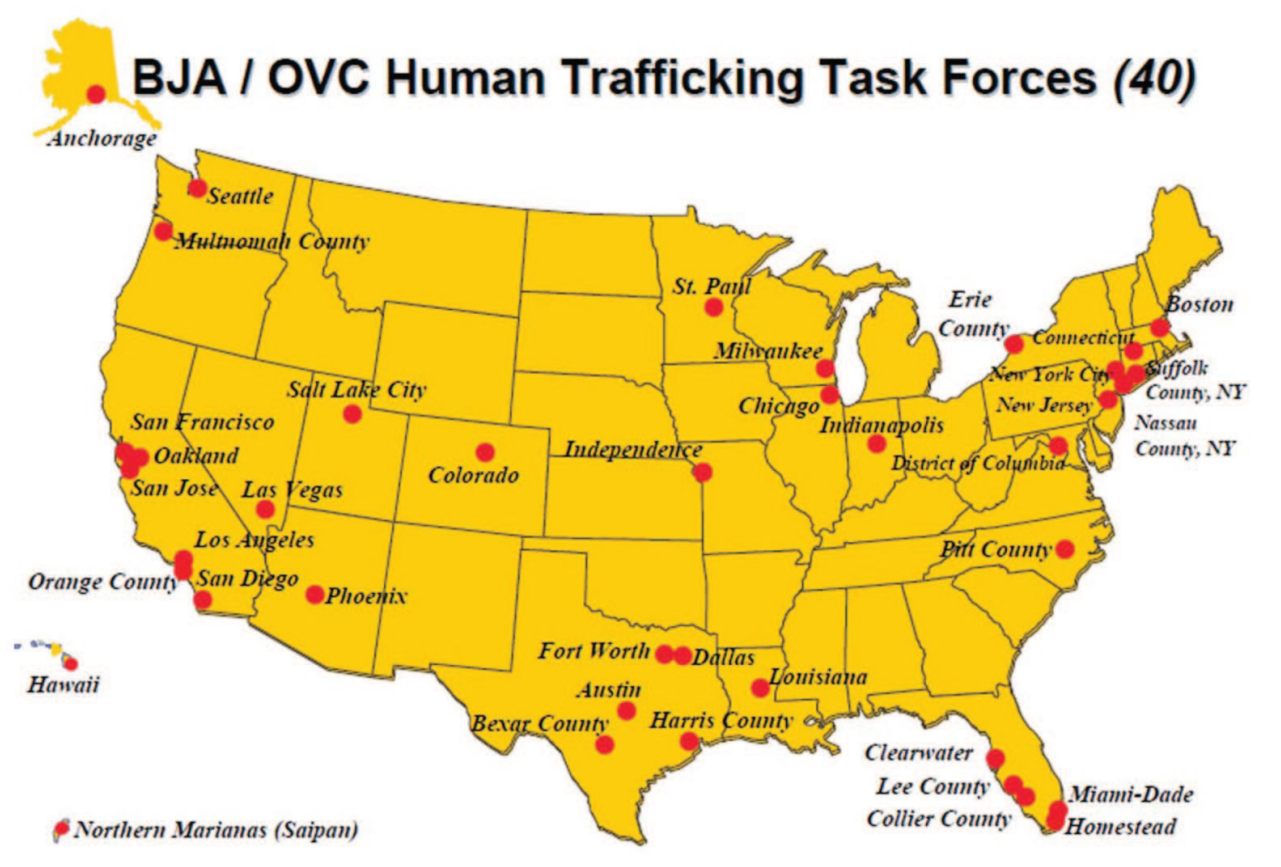

Figure 1 . U.S. Department of Justice's Bureau of Justice Assistance and Office for Victims of Crime (BJA/OVC) human trafficking task forces (40) map.

industries. In sex trafficking, victims are usually female and often underage. In labor trafficking, victims are typically male and between 18 and 24 years old (Farrell et al. 2008). However, for certain types of labor trafficking, such as domestic servitude, female adults and minors are more common among both immigrants and U.S. citizens. Perpetrators of labor trafficking tend to be 25-50 years old and overwhelmingly male. Sex trafficking perpetrators are still most frequently male, but more female traffickers are involved with sex trafficking than with labor trafficking (Farell et al. 2008; FSU-CAHR 2010; California Department of Justice 2007; FTS \& HRC-UC 2005).

Studies by Free the Slaves and the Human Rights Center, University of California, Berkeley (2005) and by Farrell et al. (2008) found perpetrators and victims to be closely matched in their nationality or ethnicity. For the HT victims, the U.S. Attorney General reported that in FY2010 certified HT victims were from 35 U.S. states, the District of Columbia, and Saipan, and from 47 countries in the Americas, Asia, Africa, and Europe (U.S. AttorneyGeneral 2011,30). For international HT victims on U.S. soil, the top countries of origin and the number of certified HT victims from each country were as shown in Table 1 and Table 2 (U.S. Attorney General 2011).

In short, human trafficking does occur in the United States, and the victims are not only foreign nationals and immigrants, but also U.S. citizens and residents, and HT has impacted both adults and children. 
Table 1. The Top 10 Countries of Origin of Certified Adult HT Victims, FY 2010

\begin{tabular}{lr}
\hline Country of origin & Number of victims \\
\hline Thailand & 95 \\
India & 90 \\
Mexico & 46 \\
Philippines & 37 \\
Haiti & 31 \\
Honduras & 24 \\
El Salvador & 19 \\
Dominican Republic & 16 \\
Guatemala & 13 \\
Peru & 9 \\
\hline
\end{tabular}

\section{Children HT Victims}

Trafficking of children differs from that of adults in that family involvement in recruitment and facilitation is much more common. Goździak et al. (2008) researched U.S. child survivors of sexual and labor trafficking through a 2005 National Institute of Justice (NIJ) grant and found that parents or grandparents were, to some degree, involved in 52 of the 56 cases researched. Child fostering is also common in many parts of the world, and it is not rare for children to be sent away to work for a relative or family friend. In the study, all of the children worked in their home countries prior to being trafficked, which may have prevented the children from viewing themselves as victims when they were trafficked to the United States.

Goździak et al. (2008) found that:

- Teenage girls faced a higher chance of being trafficked in the United States than teenage boys.

- In $70 \%$ of the cases, teenage girls were trafficked for sexual exploitation, and $24 \%$ were trafficked solely for labor and domestic servitude.

The report calls for the government to make the identification of child trafficking victims a priority, for an increase in antitrafficking resources for law enforcement, and for ongoing comprehensive training programs for immigration officials and local law enforcement.

Table 2. The Top Five Countries of Origin of the Certified Child HT Victims, FY 2010

\begin{tabular}{lr}
\hline Country of origin & Number of victims \\
\hline Mexico & 30 \\
Honduras & 27 \\
Guatemala & 12 \\
El Salvador & 9 \\
China & 8 \\
\hline
\end{tabular}




\section{Example of HT Cases in the United States}

Beyond the statistical data, here is some qualitative information on actual human trafficking cases that occurred in the United States:

- Washington, DC: Domestic workers serving foreign diplomats to the United States reported cases of abuse ranging from deprivation of wages to verbal, physical, and even sexual abuse by the diplomats, but the diplomats are protected from lawsuits due to diplomatic immunity (Luxner 2010).

- Hawaii: A forced labor case of Global Horizons, a recruiting company for the farm industry in the United States. The company was accused of abusing Thai migrant farm workers, who were forced to work for little or no pay and were held in place with threats and intimidation (U.S. Federal Bureau of Investigation 2011).

- Michigan: A forced labor case of Eastern European women who were forced to work as exotic dancers in a Detroit-area club (U.S. Federal Bureau of Investigation, Detroit Division 2011).

- Kansas City, MO: A high-ranking Taiwan representative was charged with fraud in foreign labor contracting with two Filipino housekeepers by paying low wages and forcing them to work excessive hours (U.S. Federal Bureau of Investigation, Kansas City Division 2011a).

- Kansas City, MO: Eight Uzbekistan nationals were among 12 charged with racketeering, human trafficking, and immigration violations, for withholding much of the victims' earnings from hospitality jobs in as many as 14 states and for threatening them with deportation and financial penalties if they refused to comply with the defendants' demands (U.S. Federal Bureau of Investigation, Kansas City Division 2011b).

- Native Americans in Minnesota and other states. Police reports from Duluth showed that Native American girls were being lured off reservations, taken onto ships in port, beaten, and gang-raped. Tribal advocates in South Dakota and Minnesota have also reported that Native American girls were being trafficked into prostitution, pornography, and strip shows over state lines and internationally to Mexico (Pierce and Minnesota Indian Women's Resource Center 2009, 2).

- First Iowan sentenced for "human trafficking." In 2007, two Nebraska runaway girls were recruited and harbored - age 15 and 16 at the timefor the purpose of commercial sexual activity, including prostitution and performing at strip clubs (Iowa Office of the Attorney General 2008).

\section{Conclusion}

Since Goździak and Collett (2005) reviewed the literature of human trafficking in North America, the research on human trafficking in the 
United States and the data collection processes have improved, in part because the research grants from federal agencies, such as NIJ, have focused on methodology and instruments for data collection on HT cases, most notably the project at Northeastern University that resulted in the development of the HTRS. But the USG still has more work to do on centralizing and improving its intelligence and data collection at the national level, as indicated in the latest U.S. Attorney General's report for FY2010 (U.S. Attorney General 2011, 9):

- The HSTC worked to develop a report examining different national databases and issues associated with the creation of a centralized human trafficking database.

- The Senior Policy Operating Group (SPOG) Committee on Human Trafficking Research \& Data gathered information on and compared the parameters of United States-based human trafficking databases, data sets, and domestic studies in order to enhance policymakers' understanding of the existing human trafficking data available, strengthen agency information sharing, and inform the development of antitrafficking initiatives.

In summary, the state of knowledge on human trafficking in the United States has improved, but the U.S. government and the HT research communities have much to accomplish to improve data collection methods and statistics on HT and to fill the knowledge gaps through research.

\section{Notes}

1. ORR is responsible for issuing certifications to non-U.S. citizen, non-lawful permanent resident adult victims of human trafficking who are willing to assist law enforcement in the HT investigations, and for issuing Eligibility Letters to non-U.S. citizen, non- lawful permanent resident child victims of human trafficking (i.e., minors) (U.S. Attorney General 2011, 29).

2. Garment workers as labor trafficked victims in the El Monte case (Thai Community Development Center 2012).

3. Global Horizons, a recruiting company for farm industry in the United States, was accused of abusing Thai migrant farm workers who were forced to work for little or no pay and were held in place with threats and intimidation (U.S. Federal Bureau of Investigation 2011).

\section{References}

All the websites in this article were accessed on September 28, 2012.

Banks, Duren, Tracey Kyckelhahn, and U.S. Bureau of Justice Statistics. 2011. Characteristics of suspected human trafficking incidents, 2008-2010. Bureau of Justice Statistics special report. Washington, DC: Department of Justice, Bureau of Justice Statistics. 
California Department of Justice. 2007. Human trafficking in California, Final report of the California Alliance to Combat Trafficking and Slavery Task Force. Sacramento, CA: California Attorney General's Office. http://ag.ca.gov/publications/ Human_Trafficking_Final_Report.pdf

Downes, Lawrence. 2010. In an ugly human-trafficking case, Hawaii forgets itself. New York Times, September 21, 30, http://www.nytimes.com/2010/09/21/ opinion/21tue4.html

EBSCO Publishing. 2005-2012. Library, Information Science E Technology Abstracts. Ispwich, MA: EBSCO Publishing.

Farrell, Amy, Jack McDevitt, Stephanie Fahy, and Institute on Race and Justice at Northeastern University. 2008. Understanding and improving law enforcement responses to human trafficking: Final report. Boston, MA: Institute on Race and Justice at Northeastern University. https://www.ncjrs.gov/pdffiles1/nij/ grants/222752.pdf

Florida State University Center for the Advancement of Human Rights. 2010. Florida strategic plan on human trafficking. Tallahassee, FL: Florida State University. http://www.dcf.state.fl.us/initiatives/humantrafficking/docs/FSUStrategic-Plan2010.pdf

Free the Slaves and Human Rights Center of the University of California. 2005. Hidden slaves: Forced labor in the United States. Berkeley Journal of International Law 23(1): 47-109.

Goździak, Elzbieta M., and Elizabeth A. Collett. 2005. Research on human trafficking in North America: A review of literature. International Migration 43(12): 99-128.

Goździak, Elzbieta M., and Micah N. Bump, Georgetown University Institute for the Study of International Migration, Migration and Refugee Services (United States Catholic Conference), and National Institute of Justice (U.S.). 2008. Victims no longer: Research on child survivors of trafficking for sexual and labor exploitation in the United States: Final report. Washington, DC: Institute for the Study of International Migration, Georgetown University.

Iowa Office of the Attorney General. 2008. First Iowan sentenced for "human trafficking": Leonard Ray Russell sentenced to up to 25 years in prison for human trafficking, ongoing criminal conduct, and pandering. Iowa. Department of Justice: Latest News, December 22, http://www.iowa.gov/government/ag/latest_news/releases/dec_2008/Human_Trafficking.html

Jones, Jackie. 2011. Trafficking Internet brides. Information \& Communications Technology Law 20(1): 19-33.

Kahl, Chad M., and Stephanie R. Davis-Kahl. 2010. Human rights reference sources: A critical annotated bibliography. Behavioral \& Social Sciences Librarian 29(1): 32-64.

Luxner, Larry. 2010. Oppressed nannies: State Department orders embassies to clean up their act. Washington Diplomat, November 18, http://www.washdiplomat.com $/$ index.php?option $=$ com_content\&view $=$ article\&id $=6064:$ op pressed-nannies-state-department-orders-embassies-to-clean-up-their-act\&catid=203:february-2010\&Itemid=241 
Mattar, Mohamed Y. 2004. Trafficking in persons: An annotated legal bibliography. Law Library Journal 96(4): 669-726.

Musto, Jennifer Lynne. 2009. What's in a name? Conflations and contradictions in contemporary U.S. discourses of human trafficking. Women's Studies International Forum 32(4): 281-287.

Panigabutra-Roberts, Anchalee. 2009. Human trafficking webliography. DigitalCommons@ University of Nebraska-Lincoln. http://digitalcommons.unl.edu/ humtraffdata/52

Pierce, Alexandra, and Minnesota Indian Women's Resource Center. 2009. Shattered hearts: The commercial sexual exploitation of American Indian women and girls in Minnesota. Minneapolis: Minnesota Indian Women's Resource Center. http://www.miwrc.org/about-us-section-shattered-hearts-report

Polaris Project. 2012. Majority of states actively passing laws to combat human trafficking. Polaris Project: Press Releases, August 7, http://www.polarisproject.org/media-center / press-releases / 634-majority-of-states-actively-passinglaws-to-combat-human-trafficking

Roberts, Joni R., and Carol A. Drost. 2010. Internet reviews. College E Research Libraries News 71(3): 168-169.

Stuart, Lynne. 2004. International documents roundup: The new slavery: International resources on human trafficking. DttP: Documents to the People 32(1): 9-10.

Texas Office of the Attorney General. 2008. The Texas response to human trafficking: Report to the 81st legislature. Austin, TX: Office of the Attorney General. https://oag.state.tx.us/AG_Publications/pdfs/human_trafficking_2008.pdf

Thai Community Development Center. 2012. Victory for human rights. Thai Community Development Center, http://thaicdc.org/cms/ victory-for-human-rights

United Nations. 2000. Protocol to prevent, suppress and punish trafficking in person, especially women and children. Geneva, Switzerland: United Nations.

United States. 2000. Victims of trafficking and violence protection act of 2000. Division A: Trafficking victims protection act of 2000. Washington, DC: Government Printing Office.

United States. 2008. William Wilberforce trafficking victims protection reauthorization act of 2008. Washington, DC: Government Printing Office. http://purl.access. gpo.gov/GPO/LPS109386

U.S. Attorney General. 2010. Attorney General's Annual report to Congress and assessment of the U.S. government activities to combat trafficking in persons: Fiscal year 2009. Washington, DC: Department of Justice. http://www.justice.gov/ archive/ag/annualreports/tr2009/agreporthumantrafficking2009.pdf.

U.S. Attorney General. 2011. Attorney General's Annual report to Congress and assessment of the U.S. government activities to combat trafficking in persons: Fiscal year 2010. Washington, DC: Department of Justice. http://www.justice.gov/ ag/annualreports/tr2010/agreporthumantrafficking2010.pdf

U.S. Department of Justice, Bureau of Justice Assistance and Office for Victims of Crime. 2009. BJA/OVC human trafficking task forces (40). https://www.bja. gov/Programs/40HTTF.pdf 
U.S. Federal Bureau of Investigation. 2011. Human traffickers indicted: Massive case involves 600 Thai victims. U.S. Federal Bureau of Investigation: Stories. http:// www.fbi.gov/news/stories/2011/january/trafficking_012811

U.S. Federal Bureau of Investigation, Detroit Division. 2011. Final defendant pleads guilty to his role in international conspiracy involving the forced labor of Eastern European women in Detroit-area exotic dance clubs. September 13. http:/ / www.fbi.gov/detroit/press-releases/2011/final-defendant-pleadsguilty-to-his-role-in-international-conspiracy-involving-the-forced-labor-ofeasterneuropean-women-in-detroit-area-exotic-dance-clubs

U.S. Federal Bureau of Investigation, Kansas City Division. 2011a. High-ranking Taiwan representative pleads guilty to felony charge, pays $\$ 80,000$ restitution to victims and will be deported. November 18. http://www.fbi.gov/kansascity/press-releases/2011/high-ranking-taiwan-representative-pleads-guiltyto-felony-charge-pays-80-000-restitution-to-victims-and-will-be-deported

U.S. Federal Bureau of Investigation, Kansas City Division. 2011b. Uzbek man sentenced for role in multi-national racketeering and forced labor enterprise. May 9. http:// www.fbi.gov/kansascity/press-releases/2011/uzbek-man-sentenced-for-role-in-multi-national-racketeering-and-forced-labor-enterprise

U.S. Government Accountability Office. 2006. Human trafficking: Better data, strategy, and reporting needed to enhance U.S. anti-trafficking efforts abroad. Report to the Chairman, Committee on the Judiciary, and the Chairman, Committee on International Relations, House of Representatives. Washington, DC: Government Accountability Office. http:// purl.access.gpo.gov/GPO/LPS73114

University of Nebraska-Lincoln. 2009-2011. Interdisciplinary conference on human trafficking. DigitalCommons@University of Nebraska-Lincoln. http:/ / digitalcommons.unl.edu/humantrafficking

Wisconsin Office of Justice Assistance. 2008. Hidden in plain sight: A baseline survey of human trafficking in Wisconsin. Madison, WI: Office of Justice Assistance. http://cdm16119.contentdm.oclc.org/cdm/singleitem/collection/ p267601coll4/id/967 